\title{
Silurian Spanila Barrande, 1881 (Bivalvia, Spanilidae) from European peri-Gondwana (Bohemia, Germany, France, and Austria)
}

\author{
JIŘí KŘíž
}

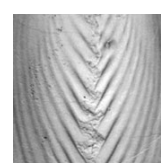

\begin{abstract}
Silurian Spanila Barrande, 1881 (Nepiomorphia Křriž, 2007) of Perunica and the European peri-Gondwana contains two species, Spanila gracilis (Münster in Goldfuss, 1837) and Spanila discipulus Barrande, 1881. It represents an important taxon-range-zone in the middle Ludfordian to the earliest Přídolí cephalopod limestone facies and may be correlated with the interval from the Neocucullograptus kozlowskii Biozone to the early Monograptus parultimus Biozone. Semi-infaunal Tetinka Barrande, 1881 from the Gorstian of Perunica was most probably the ancestor of Spanila, adapted to the specific semi-infaunal or infaunal mode of life. The assumption of semi-infaunal mode of life is supported by the cyrtiid brachiopod epibionts attached by their triangular ventral interarea to the posterior part of the shell, presumably above the level of the sediment. Spanila occupied narrow spaces between the crowded current-oriented cylindrical cephalopod shells and is commonly preserved with conjoined valves, often in the living position, i.e. with the frontal face down and parallel with bedding plane. - Key words: Bivalvia, Nepiomorphia, Silurian, systematics, evolution, palaeoecology, Perunica, European peri-Gondwana.
\end{abstract}

KŘíŽ, J. 2010. Silurian Spanila Barrande, 1881 (Bivalvia, Spanilidae) from European peri-Gondwana (Bohemia, Germany, France, and Austria). Bulletin of Geosciences 85(3), 425-434 (3 figures). Czech Geological Survey, Prague. ISSN 1214-1119. Manuscript received June 7, 2010; accepted in revised form July 28, 2010; published online September 1, 2010; issued September 30, 2010.

Jiří Kř̌ž, Czech Geological Survey, Klárov 3, P.O. Box 85, CZ-11821, Praha 1, Czech Republic; jiri.kriz@geology.cz.

The genus Spanila Barrande, 1881 (Spanilidae Kříž, 2007) was erected by Barrande (1881) for several species which he grouped in his sixth volume of "Systême Silurien" (planches 155-254) together with the genera Lunulacardium Münster, 1840, Maminka Barrande, 1881, Mila Barrande, 1881, Tenka Barrande, 1881, and Tetinka Barrande, 1881. Newell \& LaRocque (1969) included all these genera together with Stolidotus Hede, 1915 in the ?Family Lunulacardiidae Fischer, 1887. Kř́̌̌ (2007) formed the new family Spanilidae Kř́̌ž, 2007 for the genera Kenzieana Liljedahl, 1989, Spanila and Tetinka and reconstructed the family Stolidotidae Starobogatov, 1977 for the genera Stolidotus Hede, 1915, Maminka, Mila and Tenka. Later the genus Algerina Kříž, 2008 was included in the family Spanilidae. Barrande's original (1881) concept of Spanila comprised, beside the species Spanila gracilis, Spanila culter, and Spanila discipulus, also five other species I include preliminary here to the genera of Stolidotidae - Tenka aspirans (Barrande, 1881), Tenka celer (Barrande, 1881), Tenka cuneus (Barrande, 1881) and of Spanilidae - Tetinka caesarea (Barrande, 1881), and Tetinka serva (Barrande, 1881).
This paper is based on my collection from the Prague Basin (1953-2010), deposited in the Czech Geological Survey, Prague (JK). Abroad I collected in the Montagne Noire, France (1977 - the collection is deposited in the Département des Sciences de la Terre, Lyon, France) and in the Carnic Alps (1969, 1976, 1982, 1994, 1996, 1998 the collection is deposited in the Geologische Bundesanstalt, Vienna, Austria).

\section{Systematic palaeontology}

Abbreviations. - V - valve, $\mathrm{L}$ - length of the shell, $\mathrm{H}$ - height of the shell, W - width of the shell, W/2 - width of one valve (Křǐž 1969), S - stratigraphy: LL - lower Ludfordian, Ludlow, Cardiola alata Community (Kř́iž 1999a, c); ML - middle Ludfordian, Ludlow, Cardiola conformis Community (Kř́̌ž 1999a, c); UL - upper Ludfordian, Ludlow, Cardiola conformis Community (Kř́̌̌̌ 1999a, c); PR - lowermost Př́idolí, Cardiolinka bohemica Community (Kříž 1999a, c). BSPG - specimen deposited in the Bayerische Staatssammlung für Paläontologie und Geologie, München, Germany, JK - specimens deposited in the 


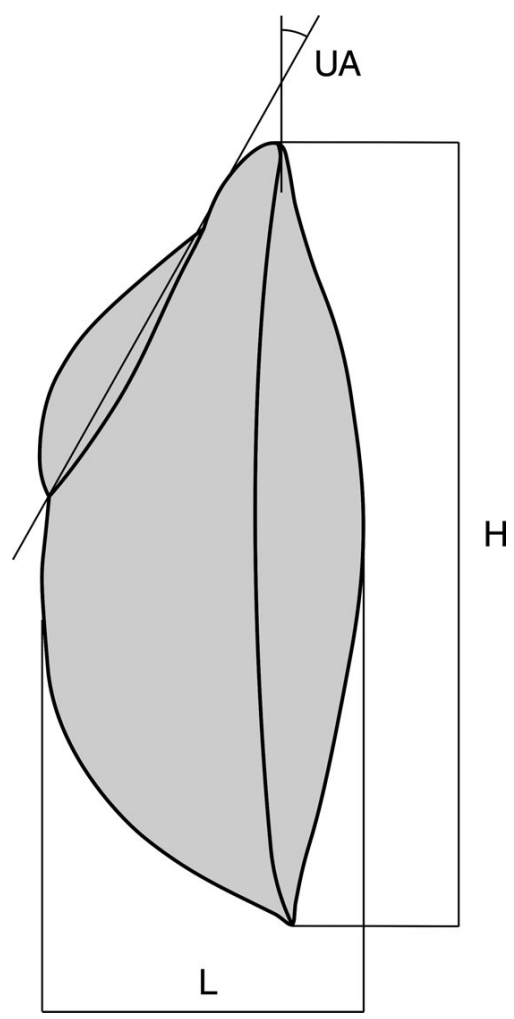

Figure 1. Schematic representation of basic morphology of the genus Spanila. $\mathrm{H}$ - height, L - length, UA - umbonal angle.

collection of Jiří Kříž in the Czech Geological Survey, Prague; NM bivalves deposited in the National Museum, Prague. All measurements are in millimetres.

Class Bivalvia Linné, 1758

Superordo Nepiomorphia Kř́iž, 2007

Order Antipleurida Kř́iž, 2007

Superfamily Dualinoidea Conrath, 1887

Family Spanilidae Kříž, 2007

\section{Spanila Barrande, 1881}

1881 Spanila Barrande, pp. 161, 162.

1881 Venusta Barrande, p. 161.

Type species. - Spanila discipulus Barrande, 1881, Bohemia, Prague Basin, Silurian, Ludlow, latest Ludfordian and early Př́idolí.

Diagnosis. - Spanilidae with small (length maximally $12.4 \mathrm{~mm}$, height maximally $28.1 \mathrm{~mm}$, and width maximally $14.2 \mathrm{~mm}$ ), dorso-ventrally elongated, narrowly obtrullate, almost equivalve, strongly inequilateral, and obese shells. Slender umbos are in central terminal position, prosogyrate. Umbonal angle $22-54^{\circ}$. Inflated, lanceolate fron- tal face separated from less steep posterior part of the shell by narrow carina, slightly curved anteriorly. Ventral margin meets blunt ridge under sharp angle, the shell narrows and becomes pointed. Close to dorsal part of the shell short wing is developed. Enantiomorphous dimorphism suppressed (shells inclined a little to the left or not inclined). Outer surface generally smoother than inner surface, radial ribs in combination with irregular growth wrinkles. Frontal face of the shell is formed by 15-29 prominent radial ribs, posteriorly of the umbonal carina or narrow ridge by $31-47$ radial ribs and behind the wing by 3-4 wide radial ribs. On the inner surface radial ribs are more prominent on frontal face. Both the radial ribs and radial gutters broaden ventrally. Cardinal area is amphidetic, triangular, and relatively high. Ligament probably monovincular. Hinge line short, straight. One long, spoon-like tooth split to two unequal parts developed on the right valve, curved dorsally and leaning against the supposed shallow sockets in the left valve. Relatively large posterior adductor muscle scar is developed close to the shell margin, in the sulcus and partly on the posterior wing. Shell thickness is $0.14-0.31 \mathrm{~mm}$.

Remarks. - The genus Spanila may be derived from the Gorstian, semi-infaunal Tetinka Barrande, 1881. The frontal face became distinctly dorsoventrally elongated during adaptation to the endobyssate and semi-infaunal mode of life in the cephalopod limestone biofacies. The hinge of Spanila has one large split tooth into unequal parts developed in the right valve. The supposed teeth in the left valve are not preserved. In contrast to Kenzieana Liljedahl, 1989 the tooth in the right valve is split to two unequal parts, the posterior is larger. Tetinka differs from Spanila mainly by blunt umbos, less developed posterior wing, outer surface sculpture with dominant growth sculptures and enantiomorphous shells inclined mostly to the right. The earliest representative of Spanila [Spanila gracilis (Münster in Goldfuss, 1837)] occurs in the middle Ludfordian, Ludlow (Neocucullograptus kozlowskii Biozone) of Bohemia, Germany (Elbersreuth, Frankenwald) and in Austria (the Carnic Alps). In the early late Ludfordian (lowermost parts of the Monograptus latilobus Biozone) occurred the main radiation of the genus Spanila. The genus Spanila became extinct in the early Přídolí.

Mode of life. - The shells of Spanila are commonly found with conjoined valves in the late Ludlow and early Přídolí cephalopod limestone levels (Kříž 1998). The cephalopod limestone biofacies originated below wave base and was influenced by surface currents (e.g. Kř́iž 1979a, b, 1999a; Ferretti \& Kř́ž 1995). Many Spanila shells are preserved in the living position with the lanceolate frontal face down, commonly parallel with the spaces between the current-oriented cephalopod shells (Fig. 2V, X), probably at least partly buried in the sediment. This is supported by the position 
of attached cyrtiid brachiopod with ventral interarea in upright position on the posterior of the Spanila gracilis (Münster in Goldfuss, 1837), presumably occurring above the level of sediment (Fig. 2S-U). It is concluded that Spanila shells were attached during life by a single byssal threads to the cephalopod empty shells or biodetrital sediment. Shells of Spanila are enantiomorphous (Kř́žz 2001), mostly inclined slightly to the left. Like Recent Pinna Linné, 1758 they were able to move slowly in narrow spaces using contraction of the foot with byssus when necessary. They were suspension filterers, and occupied the spaces between the crowded cylindrical cephalopod shells. This conclusion is supported by the abundant occurrence of the shells with conjoined valves in the cephalopod limestones, commonly even in the living position, i.e. with the frontal face down and parallel with bedding plane.

Species and distribution. - Spanila gracilis: the middle Ludfordian, Ludlow (Neocucullograptus kozlowskii Biozone) of Bohemia (Prague Basin), Germany (Elbersreuth, Frankenwald and Giessen, Lindener Mark), France (the Montagne Noire, Mouthoumet Massif), and Austria (Dienten near Salzburg and the Carnic Alps), and the late Ludfordian and earliest Přídolí of Bohemia. Spanila discipulus Barrande, 1881: the late Ludfordian and earliest Přídolí of Bohemia.

\section{Spanila gracilis (Münster in Goldfuss, 1837)}

Figure 2A-X

1837 Cardium gracile Münster; Goldfuss, p. 215, pl. 142, figs $6 a-e$.

1840 Cardium gracile. - Münster, p. 61.

1881 Spanila gracilis Barr. - Barrande, pl. 214, figs I/1-8.

1925 Amita gracilis Mstr. sp. - Heller, pp. 220-227, pl. 7, figs a-c.

1929 Amita (Spanila) cardiopsis Barr. - Heritsch, pp. 9, 10, pl. 4, figs 342-349.

1953 Spanila gracilis Barr. - Kegel, p. 51, pl. 3, figs 7a, b.

1953 Spanila aspirans Barr. - Kegel, pp. 51, 52, pl. 3, figs $8 \mathrm{a}-\mathrm{c}, 9 \mathrm{a}, \mathrm{b}$.

1953 Spanila acuta n. sp. - Kegel, p. 53, pl. 3, figs 11a, b.

1996 Spanila gracilis Barr. - Kříž, p. 53, pl. 6, figs 8, 9.

1999b Spanila gracilis Barr. - Kříž, p. 298, pl. 9, figs 8, 14.

Holotype. - (By monotypy) shell with conjoined valves figured by Münster in Goldfuss (1837) on pl. 142 as figs 6a-e, deposited in the Bayerische Staatssammlung für Paläontologie und Geologie, München, Germany, AS VII 1758.

Type locality. - Germany, Frankenwald, Elbersreuth.

Type horizon. - Ludlow, Ludfordian.
Material. - 82 shells with conjoined valves, 104 left and 95 right valves.

Diagnosis. - Small, narrow Spanila with narrowly obtrulate or angular-obovate in outline, dorso-ventrally elongated $(\mathrm{H} / \mathrm{L}=1.5-2.4)$, strongly inflated shells. Umbonal angle $30-53^{\circ}$. Moderately inflated, lanceolate frontal face steeper than posterior part of the shell, with 22-29 well developed radial ribs, separated from the central part of the shell with 31-47 radial ribs by prominent narrow carina curved anteriorly and pointed ventrally. Enantiomorphous (mostly inclined slightly to the left).

Description. - Shell small (length maximally $12.4 \mathrm{~mm}$, height maximally $28.1 \mathrm{~mm}$, and width maximally $14.2 \mathrm{~mm}$ ), slightly inequivalve, strongly inequilateral, prosocline, narrowly obtrullate or angular-obovate in outline. They are dorso-ventrally elongated, and strongly inflated. In adult shells the height/length relation $(\mathrm{H} / \mathrm{L})$ ranges from 1.5 to 2.4. Enantiomorphous dimorphism supressed (shells inclined mostly slightly to the left). Blunt umbos in central terminal position, formed by mesoconch, prosogyrate. Umbonal angle $37-53^{\circ}$. Slighty inflated, angular obovate frontal face very steep and wide, separated from the central part of the shell by prominent narrow carina, almost straight or curved anteriorly and pointed ventrally. Ventral margin meets blunt ridge under sharp angle, the shell here narrows and becomes pointed. The small and narrow posterior wing separated from the rest of shell by radial sulcus. Outer surface of frontal face is formed by 15-19 rounded radial ribs, posteriorly of the carina are $31-47$ radial ribs. Posteriorly of the wing the shell is formed by 3-4 wide radial ribs. Both the radial ribs and radial gutters broaden ventrally and slightly increase in number during the life of individual. The ribs on the outer surface are less prominent than on the inner surface. Exceptionally the radial sculpture is almost supressed in the outer surface and only radial crenulations are developed on inner surface sculpture on the shell margin. Narrow growth bands regular in umbonal part narrows and become irregular and narrower ventrally. Relatively large posterior adductor scar developed close to the shell margin, in the sulcus and partly on the posterior wing. Cardinal area amphidetic, triangular, small and relatively high. Ligament probably monovincular. Shell thickness is $0.14-0.31 \mathrm{~mm}$.

Ontogeny.- Prodissoconch not known. Mesoconch equivalve, inequilateral, obliquely obtriangular, prosogyrate, separated from adult shell by a distinct growth furrow caused by increase of the commissural angle (Kř́ž 1979a). Outer and inner surface smooth or with supressed radial ribs. In the small, juvenile shells the $\mathrm{H} / \mathrm{L}$ ratio is usually small (1.5-1.6). During ontogeny the L/W and $\mathrm{H} / \mathrm{W}$ ratio increases ( $\mathrm{L} / \mathrm{W}$ ratio from 0.6 to 1 and $\mathrm{H} / \mathrm{W}$ ratio 
from 1.4 to 2.2), shells become relatively higher, umbonal angle decreases as well as width in relation to height. The average height of adult shells varies from 10 to $15 \mathrm{~mm}$. The shells with the height more than $20 \mathrm{~mm}$ are rare and occur in the late Ludlow. The maximum known height is $27.9 \mathrm{~mm}$.

\section{Dimensions. -}

\begin{tabular}{|c|c|c|c|c|c|c|c|c|}
\hline Specimen & V & $\mathrm{L}$ & $\mathrm{H}$ & width $/ 2$ & $\mathrm{~L} / \mathrm{W}$ & $\mathrm{H} / \mathrm{W}$ & $\mathrm{H} / \mathrm{L}$ & $\mathrm{S}$ \\
\hline JK 11 141a & $\mathrm{R}$ & 4.1 & 8.6 & 2.5 & 0.8 & 1.7 & 2.0 & UL \\
\hline JK 4837 & $\mathrm{R}$ & 4.1 & 9.6 & 3.0 & 0.6 & 1.6 & 2.3 & UL \\
\hline JK 8996 & $\mathrm{~L}$ & 4.3 & 6.6 & 2.1 & 1.0 & 1.6 & 1.5 & ML \\
\hline NM L 21758 & $\mathrm{~L}$ & 4.3 & 11.2 & 3.6 & 0.6 & 1.6 & 2.6 & UL \\
\hline JK 2963 & $\mathrm{R}$ & 4.4 & 7.1 & 2.1 & 1.0 & 1.7 & 1.6 & UL \\
\hline JK 11094 & $\mathrm{~L}$ & 4.6 & 7.2 & 2.5 & 0.9 & 1.4 & 1.6 & LL \\
\hline JK 4836 & $\mathrm{R}$ & 4.7 & 10.0 & 3.0 & 0.8 & 1.7 & 2.1 & UL \\
\hline JK 8988 & $\mathrm{~L}$ & 4.9 & 7.6 & 2.6 & 0.9 & 1.5 & 1.6 & PR \\
\hline JK 4931 & $\mathrm{R}$ & 5.0 & 11.0 & 3.3 & 0.8 & 1.7 & 2.2 & UL \\
\hline JK 4838 & $\mathrm{R}$ & 5.4 & 11.6 & 3.5 & 0.8 & 1.7 & 2.1 & UL \\
\hline JK 4970 & $\mathrm{~L}$ & 5.5 & 10.8 & 3.6 & 0.8 & 1.5 & 2.0 & ML \\
\hline BSPG AS VII 1758 & $\mathrm{~L}$ & 5.6 & 13.6 & 3.4 & 0.8 & 2.0 & 2.4 & LL \\
\hline JK 2985 & $\mathrm{~L}$ & 5.7 & 11.4 & 3.6 & 0.8 & 1.6 & 2.0 & UL \\
\hline JK 8916 & $\mathrm{R}$ & 5.7 & 12.6 & 3.2 & 0.9 & 2.0 & 2.2 & UL \\
\hline JK 8993 & $\mathrm{~L}$ & 5.7 & 12.5 & 4.6 & 0.6 & 1.4 & 2.2 & UL \\
\hline JK 4951 & $\mathrm{~L}$ & 6.4 & 12.2 & 3.0 & 1.1 & 2.0 & 1.9 & UL \\
\hline JK 8980 & $\mathrm{R}$ & 6.4 & 13.0 & 3.7 & 0.9 & 1.8 & 2.0 & UL \\
\hline JK 8906 & $\mathrm{~L}$ & 6.4 & 13.5 & 3.7 & 0.9 & 1.8 & 2.1 & UL \\
\hline JK 8923 & $\mathrm{~L}$ & 6.4 & 13.9 & 3.6 & 0.9 & 1.9 & 2.2 & UL \\
\hline JK 4967 & $\mathrm{~L}$ & 6.5 & 10.9 & 3.7 & 0.9 & 1.5 & 1.7 & UL \\
\hline JK 8985 & $\mathrm{R}$ & 7.1 & 14.1 & 3.8 & 0.9 & 1.9 & 2.0 & PR \\
\hline JK 8954 & $\mathrm{R}$ & 7.3 & 15.1 & 4.3 & 0.8 & 1.8 & 2.1 & UL \\
\hline
\end{tabular}

\begin{tabular}{|c|c|c|c|c|c|c|c|c|}
\hline JK 2977 & $\mathrm{R}$ & 7.5 & 15.5 & 4.8 & 0.8 & 1.6 & 2.1 & PR \\
\hline JK 2987 & $\mathrm{~L}$ & 7.7 & 17.1 & 4.0 & 1.0 & 2.1 & 2.2 & UL \\
\hline JK 4978 & $\mathrm{~L}$ & 8.1 & 16.3 & 4.6 & 0.9 & 1.8 & 2.0 & UL \\
\hline JK 8944 & $\mathrm{~L}$ & 8.2 & 15.3 & 3.7 & 1.1 & 2.1 & 1.9 & UL \\
\hline JK 8933 & $\mathrm{R}$ & 8.3 & 15.5 & 4.0 & 1.0 & 1.9 & 1.9 & UL \\
\hline JK 8992 & $\mathrm{R}$ & 8.4 & 16.7 & 5.2 & 0.8 & 1.6 & 2.0 & UL \\
\hline JK 2986 & $\mathrm{~L}$ & 8.4 & 17.5 & 4.6 & 0.9 & 1.9 & 2.1 & UL \\
\hline JK 4859 & $\mathrm{R}$ & 8.5 & 13.0 & 4.2 & 1.0 & 1.5 & 1.5 & UL \\
\hline JK 4957 & $\mathrm{~L}$ & 8.5 & 17.4 & 4.5 & 0.9 & 1.9 & 2.0 & UL \\
\hline JK 8970 & $\mathrm{~L}$ & 8.7 & 17.7 & 4.7 & 0.9 & 1.9 & 2.0 & UL \\
\hline JK 2983 & $\mathrm{R}$ & 8.8 & 17.1 & 4.8 & 0.9 & 1.8 & 1.9 & UL \\
\hline JK 4834 & $\mathrm{R}$ & 8.8 & 19.0 & 4.6 & 1.0 & 2.1 & 2.2 & PR \\
\hline JK 8932 & $\mathrm{~L}$ & 9.1 & 18.2 & 4.5 & 1.0 & 2.0 & 2.0 & UL \\
\hline JK 8928 & L & 9.4 & 17.3 & 5.2 & 0.9 & 1.7 & 1.8 & UL \\
\hline JK 4706 & $\mathrm{R}$ & 9.6 & 20.4 & 5.0 & 1.0 & 2.0 & 2.1 & UL \\
\hline JK 8968 & $\mathrm{R}$ & 9.7 & 21.5 & 5.3 & 0.9 & 2.0 & 2.2 & UL \\
\hline JK 11014 & $\mathrm{~L}$ & 9.9 & 18.2 & 5.7 & 0.9 & 1.6 & 1.8 & ML \\
\hline JK 8952 & $\mathrm{~L}$ & 10.2 & 21.0 & 4.8 & 1.1 & 2.2 & 2.1 & UL \\
\hline NM L 26522 & $\mathrm{~L}$ & 10.2 & 24.6 & 6.8 & 0.8 & 1.8 & 2.4 & UL \\
\hline JK 2989 & $\mathrm{~L}$ & 10.3 & 21.2 & 5.1 & 1.1 & 2.1 & 2.1 & UL \\
\hline JK 8942 & $\mathrm{R}$ & 10.3 & 21.4 & 5.8 & 0.9 & 1.8 & 2.1 & UL \\
\hline JK 4843 & $\mathrm{~L}$ & 10.6 & 20.7 & 5.1 & 1.0 & 2.0 & 2.0 & UL \\
\hline JK 4858a & $\mathrm{R}$ & 10.7 & 21.2 & 6.5 & 0.8 & 1.6 & 2.0 & UL \\
\hline JK 8995 & $\mathrm{R}$ & 10.8 & 21.6 & 6.0 & 0.9 & 1.8 & 2.0 & UL \\
\hline JK 8849 & $\mathrm{R}$ & 12.0 & 27.9 & 7.1 & 0.8 & 2.0 & 2.3 & UL \\
\hline
\end{tabular}

Remarks. - Ancestors of Spanila gracilis appearing in the lower Ludfordian of peri-Gondwana were most probably among the Gorstian representatives of the genus Tetinka. Most probably the direct descendant of Spanila gracilis

Figure 2. A-X-Spanila gracilis (Münster in Goldfuss, 1837). • A-C - shell with conjoined valves, internal mould, BSPG AS VII 1758 , holotype, original Münster in Goldfuss (1837, pl. 142, fig. 6); A - left lateral view, $\times 3.1$; B - right lateral view, $\times 3.1$; C - anterior view, frontal face, $\times 3.1$. $・$ D - left valve, internal mould, JK 8937 , lateral view, $\times 3.4$. $\bullet$ E - juvenile right valve, JK 2963 , lateral view, $\times 4.3$. $\bullet$ F, G - shell with conjoined valves, recrystallized shell preserved, NM L 21758, original Barrande (1881, pl. 214, figs 6-8); F - right lateral view, $\times 3.6$; G - anterior view, frontal face, $\times 3.6$. $\bullet \mathrm{H}, \mathrm{I}, \mathrm{M}$ - right valve, internal mould, JK $8942 ; \mathrm{H}$ - posterior view, $\times 2.5 ; \mathrm{I}-$ lateral view, $\times 2.5 ; \mathrm{M}-$ dorsal view, $\times 3.5$. $\bullet \mathrm{J}-\mathrm{left}$ valve, internal mould, JK 2986, lateral view, $\times 5.3$. $\bullet \mathrm{K}, \mathrm{L}$ - right valve, internal mould, JK $8992 \mathrm{a}$; K - lateral view, $\times 3$; L - anterior view, frontal face, $\times 3$. $\bullet \mathrm{N}-$ shell with conjoined valves, internal mould, NM L 26 522, original Barrande (1881, pl. 214, figs I/1-5), ventral view, $\times 2.6$. $\bullet$ - left valve, internal mould, JK 8931, detail of the posterior adductor muscle scar, $\times 6.2 . \bullet P$ - right valve, internal mould, JK 8995 , detail of cardinal area, $\times 5.6$. $\bullet \mathrm{R}-$ left valve, JK 8966 , detail of the outer and inner surface sculpture in posterior part of the valve, $\times 4.7 . \bullet \mathrm{S}-$ shell with conjoined valves, inner surface with shell pathology, JK $11141 \mathrm{a}$, right lateral view, $\times 7.5 \cdot \bullet \mathrm{T}, \mathrm{U}-$ left valve, inner surface with shell pathology, JK 2961; T - lateral view, $\mathrm{x}$ 4.8; U - posterolateral view, $\times 4.2$. $\bullet \mathrm{V}, \mathrm{X}-$ shell with conjoined valves preserved in the living position on the upper bedding plane of the cephalopod limestone, JK 8918; V - posterior view, $\times 3.3$; $\mathrm{X}$ - posterolateral view, $\times 8.6$. $•$ A-C - Elbersreuth locality, Frankenwald, Germany, Neocucullograptus kozlowskii Biozone, middle Ludfordian, Ludlow. • D, H, I, M, O, R, V, X - Praha-Pankrác, Sdružení Street locality, Cardiola conformis Community (Kř́̌ž 1999a, c), upper Ludfordian, Ludlow. • E-G, J, P, T, U - Praha-Lochkov, Cephalopod Quarry locality, Cardiola conformis Community (Křiž 1999a, c), upper Ludfordian, Ludlow. • K - Beroun, Kosov Quarry locality, uppermost Cardiola conformis Community (Kř́̌ž 1999a, c), upper Ludfordian, Ludlow. • N, S - Kosoř, Barrandes test pits, Cardiola conformis Community (Křǐž 1999a, c), upper Ludfordian, Ludlow. 


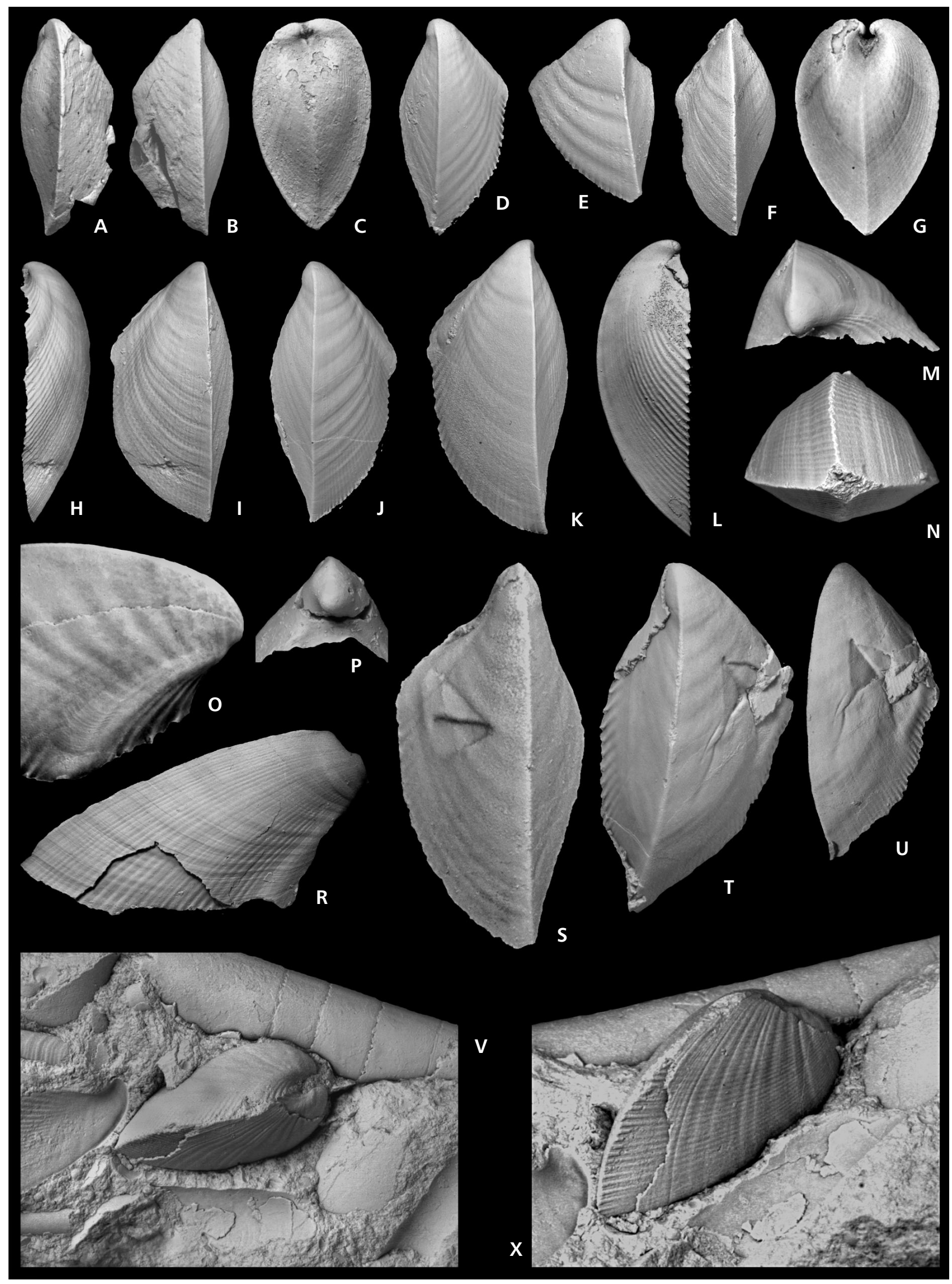


(Münster in Goldfuss, 1837) is Spanila discipulus Barrande, 1881, occurring in the late Ludfordian cephalopod limestones of the Prague Basin. It differs in having a mesoconch with prominent radial ribs, in its generally slender, distinctly dorsoventrally elongated narrow adult shell with reduced number of radial ribs. In contrast to 31-47 ribs in Spanila gracilis in Spanila discipulus only 6-11 radial ribs are developed posteriorly of the carina.

Shell pathology. - On the interior of the shell with conjoined valves (Kosoř locality, upper Ludfordian, JK 11141a, fig. 2S) and on another single valve (Praha-Lochkov, Cephalopod Quarry locality, latest Ludfordian, JK 2961, Fig. 2T, U) is preserved an almost identical triangular impression caused most probably by some organism attached during the life of bivalve to its outer surface. Both specimens were found in two distant localities and in slightly different stratigraphic levels in the Prague Basin, Bohemia. The organism was most probably only attached to the shell wall and did cause only small deformations in the shell growth.

Spanila gracilis is supposed to be attached by byssal threads with the subhorizontal frontal face to the substrate. Triangular impressions on the shell are situated posteriorly of the carina (above), with the hypotenuse of the triangle up and the vertex down. Between vertex and centre of hypotenuse is a prominent narrow rounded gutter, increasing in width from vertex up.

The triangular impression very much recalls the imprint of the ventral interarea of the juvenile cyrtiid brachiopods, which served for attachment to the substratum, commonly to other shells on the bottom. According to Ivanova (1962) and Havlíček in Havlíček \& Štorch (1990), on the triangular area is the delthyrium completely covered by a convex plate, which corresponds to the narrow gutter in the impression. The cyrtiids were only attached, not incrustated by their ventral interarea to the substratum (Ivanova 1962, p. 31). This is most probably the reason why mantle was not so irritated to produce a malformed shell below the attachment (Boschoff 1968), so the shell exhibits the normal growth on the posterior margin with radial ribs produced posteriorly (above) of the impression. The impression intervened slightly to the shell interior.

The living position of cyrtiids is with the dorsal valve up. It corresponds exactly with the shape and orientation of the impressions of the ventral interarea of juvenile cyrtiids on the surface of the valve but it is impossible to determine the exact species. In the late Ludfordian of the Prague Basin several species of cyrtiids occurs having a similar ventral interarea: Cyrtia humilis Bouček, 1941, Cyrtia postera Bouček, 1941, and Cyrtia maior ludlowensis Bouček, 1941.

Occurrence. - Bohemia, Prague Basin - middle Ludfordian, Cardiola alata Community: Praha- ̌̌eporyje - Požáry section, Beroun - Kosov Quarry. Upper Ludfordian, early Cardiola conformis Community: Beroun - Kosov Quarry, Praha-Pankrác - Sdružení Street locality, Praha-Butovice. Upper Ludfordian: Praha-Velká Chuchle, Praha-Lochkov - Barrande's test-pits, Praha-Slivenec, Kosoř, Praha-Radotín Valley - Hvížd’alka section. Uppermost Ludfordian, Cardiola conformis Community: Praha-Malá Chuchle - Vyskočilka locality, Praha-Pankrác - temporary outcrop for the TV Studio and Sdružení Street locality, Praha-Butovice, Praha-Lochkov - Cephalopod Quarry, Praha-Zadní Kopanina, Praha-Radotín Valley, U topolů section, Beroun - Kosov Quarry. Lowermost Přídolí: Praha-Lochkov - Cephalopod Quarry, Praha-Radotín Valley, U topolù section. The middle Ludfordian, Ludlow (Neocucullograptus kozlowskii Biozone) of Germany - Elbersreuth, Frankenwald (Greiling 1962, Heller 1925, Münster in Goldfuss 1837, Münster 1840), and Alfredscacht near Giessen, Lindener Mark (Kegel 1953), France - Vigne de M. Sourgnes, north of Félines-Termenés, Mouthoumet Massif, the Montagne Noire (Křǐž 1996), and Austria - Nagelschmiedpalfen near Dienten, Salzburg (Heritsch 1929, Kř́ž 1979a) and the Base of Seewarte, Carnic Alps (Kříž 1999b).

Figure 3. A-X - Spanila discipulus Barrande, 1881. • A - shell with conjoined valves, outer surface, JK 8761, posterior view, $\times 5.1$. $\bullet$ B-F - shell with conjoined valves, internal mould with fragments of recrystallized shell, JK 8993 ; B - left lateral view, $\times 3$; C - right lateral view, $\times 3$; D - dorsal view, $\times 2.8$; E - anterior view, frontal face, $\times 3 ; \mathrm{F}-$ posterior view, $\times 3 . \bullet \mathrm{H}-$ shell with conjoined valves, inner surface, JK 8981 , detail of the hinge, right valve up, latex mould, $\times 11.3$. $\bullet \mathrm{I}-\mathrm{O}-$ shell with conjoined valves, internal mould, JK $11142 \mathrm{a} ; \mathrm{I}-$ right lateral view, $\times 2.8 ; \mathrm{J}-\mathrm{left}$ lateral view, $\times 2.8 ; \mathrm{K}-$ ventral view, $\times 4.2 ; \mathrm{L}-$ dorsal view, $\times 4.3 ; \mathrm{M}-$ anterior view, frontal face, $\times 2.8 ; \mathrm{N}-$ posterior view, $\times 2.8 ; \mathrm{O}-$ posterodorsal view, detail of mesoconchs with recrystalized shell partly preserved, $\times 10.1 . \cdot \mathrm{P}-\mathrm{R}-$ left valve, internal mould with fragment of recrystallized shell on the frontal face, JK 11031; P - detail of inner and outer surface sculpture, $\times 7.7 ; \mathrm{R}$ - lateral view, $\times 2.7 . \cdot \mathrm{S}-$ shell with conjoined valves, internal mould with most of the recrystallized shell preserved, NM L 26521, original Barrande (1881, pl. 213, figs III/5-8), paralectotype, left lateral view, $\times 3.4$. $\bullet$ T-X - shell with conjoined valves, internal mould, original Barrande (1881, pl. 213, figs III/1-4), lectotype, NM L 26519; T - right lateral view, $\times 3.1$; U - left lateral view, $\times 3.1 ; \mathrm{V}$ - anterior view, frontal face, $\times 3.1 ; \mathrm{X}-$ posterior view, $\times 3.1 . \bullet \mathrm{A}, \mathrm{S}-$ Praha-Lochkov, Barrande's test pits, Cardiola conformis Community (Kř́ž 1999a, c), upper Ludfordian, Ludlow. • B-F, H, P-R - Praha-Lochkov, Cephalopod Quarry locality, uppermost Cardiola conformis Community (Kř́iž 1999a, c), uppermost Ludfordian, Ludlow. • I-O - Kosoř, Cardiola conformis Community (Kř́ž 1999a, c), upper Ludfordian, Ludlow. Ludlow. • G, T-X - Praha-Dvorce quarry, uppermost Cardiola conformis Community (Kř́̌ž 1999a, c), uppermost Ludfordian, Ludlow. 


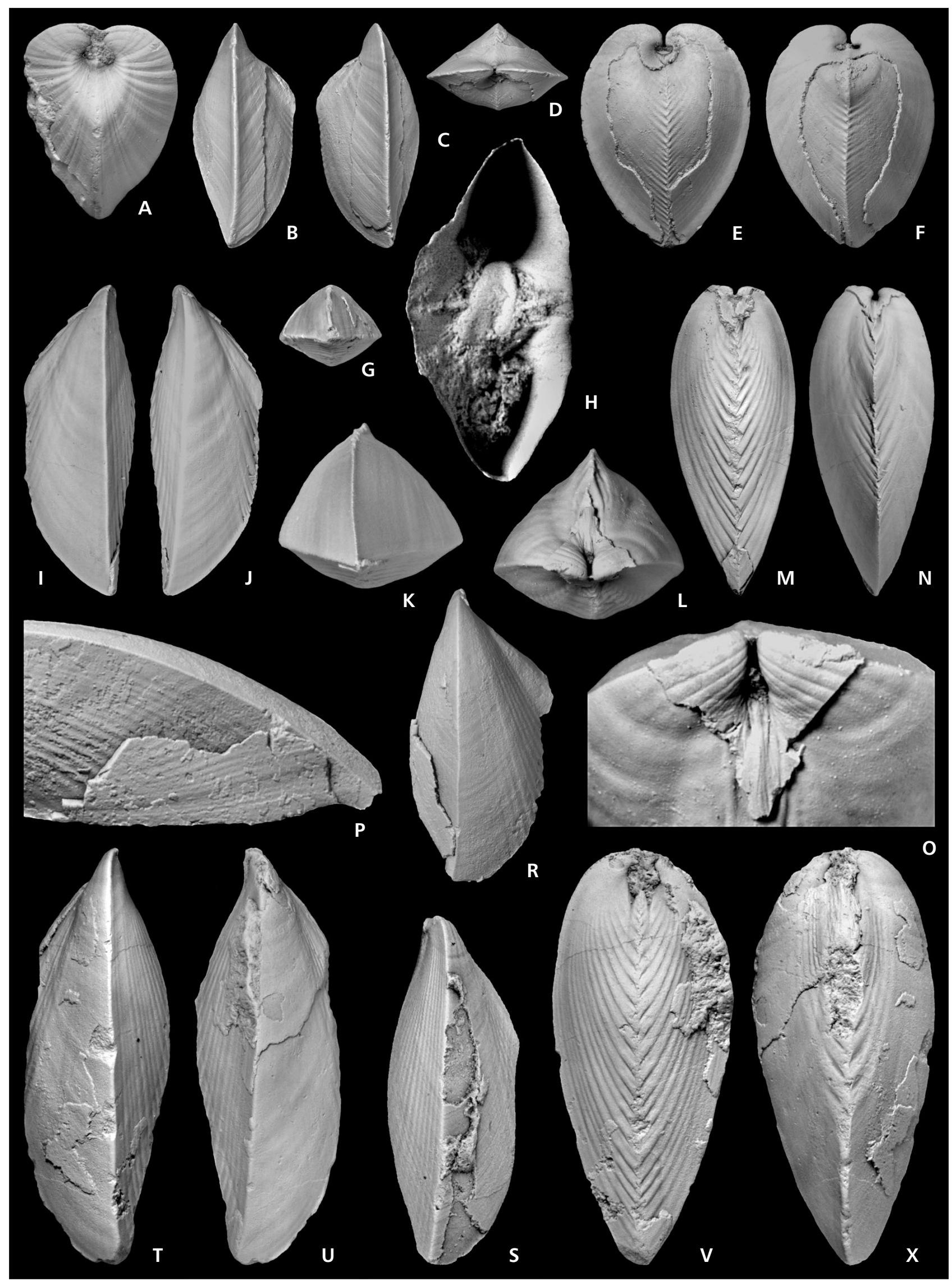




\section{Spanila discipulus Barrande, 1881}

Figure 3A-X

1881 Spanila discipulus Barr.; Barrande, pl. 212, figs III/1-8. 1881 Spanila culter Barr.; Barrande, pl. 212, figs I/1-6.

1881 Goniophora phrygia Barr.; Barrande, pl. 195, figs V/1-4.

Lectotype. - (SD Růžička \& Prantl, 1960, p. 54) Internal mould of the shell with conjoined valves and with fragments of the recrystalized shell figured by Barrande (1881) on pl. 213 as figs III/1-4, NM L 26519 and refigured herein on Fig. 3T-X.

Paralectotype. - The other specimen figured by Barrande (1881) on pl. 213, figs III/5-8, NM L 26521 and refigured herein on Fig. $3 \mathrm{~S}$.

Type locality. - Bohemia, Prague Basin, Praha-Dvorce.

Type horizon. - Ludlow, latest Ludfordian.

Material. - 13 shells with conjoined valves, 7 left and 3 right valves.

Diagnosis. - Small Spanila with dorso-ventrally elongated (H/L = up to 3.1), narrowly obtrulate, slightly inequivalve, inequilateral, inflated shells. Close to dorsal part of the shell elongated, short, obtuse wing is developed. Umbonal part is slender, umbos in central terminal position, prosogyrate. Umbonal angle is $22-47^{\circ}$. Moderately inflated, lanceolate frontal face steeper than posterior part of the shell, with 9-15 well developed radial ribs, separated from the central part of the shell with 6-11 radial ribs by prominent narrow carina curved anteriorly. Enantiomorphous shells inclined mostly a little to the left. Hinge line short, straight. One long, spoon-like tooth split to unequal parts developed on the right valve, curved dorsally and leaning against the supposed shallow sockets in the left valve.

Description. - Shell small (length maximally $8.6 \mathrm{~mm}$, height maximally $24 \mathrm{~mm}$, and width maximally $10.6 \mathrm{~mm}$ ), narrowly obtrulate, slightly inequivalve, inequilateral, dorso-ventrally elongated $(\mathrm{H} / \mathrm{L}=1.9-3.1)$, inflated. Close to dorsal part of the shell short wing is developed. Enantiomorphous shells inclined mostly a little to the left or not inclined. Inflated, lanceolate frontal face separated from less steep posterior part of the shell by prominent narrow carina, slightly curved anteriorly and pointed ventrally. Prominent, slender umbos are in central terminal position, formed by mesoconch with radial ribs, prosogyrate. Umbonal angle is $22-47^{\circ}$. Ventral margin meets blunt ridge under sharp angle, the shell here narrows and becomes pointed. Posterior wing elongated, short, obtuse. Outer surface generally smoother than inner surface, radial ribs in combi- nation with irregular growth wrinkles. On the frontal face of the shell 15-19 prominent radial ribs are developed. Posteriorly of carina the shell is first almost smooth, than 6-11 radial ribs are developed close to the wing; posteriorly of wing the shell is formed by $3-4$ less prominent radial ribs. On the inner surface radial ribs are more prominent on frontal face, regularly spaced, separated by radial gutters. Both the radial ribs and radial gutters broaden ventrally. Hinge line short, straight. One long, spoon-like tooth split to two unequal parts developed on the right valve, curved dorsally and leaning against the supposed shallow sockets in the left valve. Posterior adductor muscle scar is developed on the posterior wing close to the shell margin. Shell thickness is $0.14-0.28 \mathrm{~mm}$.

Ontogeny. - Prodissoconch not known. Mesoconch equivalve, obliquelly obtriangular, inflated $(\mathrm{H} / \mathrm{W}=1.2-1.5)$, inequilateral $(\mathrm{H} / \mathrm{L}=2-2.6)$. Blunt umbos are prosogyrate. The height of known shells varies from 3-4.4 mm. The frontal face is much steeper than posterior part of the shell. The anteriorly curved blunt edge separates frontal face from the posterior part of the shell. Outer surface sculpture with several regularly spaced, relatively wide growth bands in combination with prominent radial ribs ( 8 wide ribs developed on anterior face, posterior with 5 wide ribs plus 3 narrow radial ribs developed just before wing plus 3 narrow ribs posterodorsally of the wing). The prominent radial ribs practically disappear in the last growth furrow of mesoconch. On inner surface the ribs are just slightly developed and continue to adult stage. During further growth the shell becomes distinctly slender, dorsoventrally elongated $(\mathrm{H} / \mathrm{L}=1.9-3.1)$ with length and width equal $(\mathrm{L} / \mathrm{W}=0.4-1.1)$. $\mathrm{H} / \mathrm{W}$ ratio increases (1.1-3.4). The umbonal angle decreases from $47^{\circ}$ to $22^{\circ}$. Blunt edge between frontal face and the shell posterior turns to carina. Number of radial ribs increase. Frontal face of the shell is formed by 15-19 prominent radial ribs. Posterior of the shell is first almost smooth, with 6-11 radial ribs close to the wing; posteriorly of wing 3-4 less prominent radial ribs are developed. The maximum known height is $24 \mathrm{~mm}$.

\section{Dimensions. -}

$\begin{array}{lcccrcccc}\text { Specimen } & \text { V } & \text { L } & \text { H } & \text { width/2 } & \text { L/W } & \text { H/W } & \text { H/L } & \text { S } \\ \text { JK 11 142a } & \text { R } & 1.5 & 3.0 & 1.3 & 0.6 & 1.2 & 2.0 & \text { UL } \\ \text { JK } 8770 & \text { L } & 1.7 & 4.4 & 1.5 & 0.6 & 1.5 & 2.6 & \text { UL } \\ \text { JK 8761 } & \text { R } & 3.3 & 7.1 & 2.5 & 0.7 & 1.4 & 2.2 & \text { UL } \\ \text { JK 11 126 } & \text { R } & 5.3 & 11.0 & 3.2 & 0.8 & 1.7 & 2.1 & \text { UL } \\ \text { JK 11 246 } & \text { R } & 5.6 & 10.9 & 3.3 & 0.8 & 1.7 & 1.9 & \text { UL } \\ \text { JK 11 246 } & \text { L } & 5.6 & 10.9 & 3.8 & 0.7 & 1.4 & 2.0 & \text { UL } \\ \text { JK } 8993 & \text { R } & 5.8 & 12.7 & 4.1 & 0.7 & 1.6 & 2.2 & \text { UL }\end{array}$




$\begin{array}{lllllllll}\text { NM L 21 415 } & \text { R } & 5.8 & 17.3 & 3.3 & 0.9 & 2.6 & 3.0 & \text { UL } \\ \text { NM L 26 521 } & \text { L } & 6.9 & 18.2 & 4.1 & 0.8 & 2.2 & 2.6 & \text { UL } \\ \text { JK 2982 } & \text { L } & 6.9 & 19.0 & 3.5 & 1.0 & 2.7 & 2.8 & \text { PR } \\ \text { JK 11 000 } & \text { R } & 7.0 & 18.8 & 4.5 & 0.8 & 2.1 & 2.7 & \text { UL } \\ \text { JK 8770 } & \text { L } & 7.0 & 21.2 & 4.3 & 0.8 & 2.4 & 3.0 & \text { UL } \\ \text { JK 11 142a } & \text { L } & 7.1 & 19.7 & 3.3 & 1.1 & 3.0 & 2.8 & \text { UL } \\ \text { JK 11 142a } & \text { R } & 7.1 & 19.7 & 4.2 & 0.8 & 2.3 & 2.8 & \text { UL } \\ \text { JK 8752 } & \text { L } & 7.3 & 19.8 & 3.7 & 1.0 & 2.7 & 2.7 & \text { UL } \\ \text { JK 8999 } & \text { R } & 7.4 & 21.5 & 3.7 & 1.0 & 2.9 & 2.9 & \text { UL } \\ \text { JK 3543 } & \text { L } & 7.7 & 23.5 & 3.5 & 1.1 & 3.4 & 3.1 & \text { UL } \\ \text { JK 4993 } & \text { L } & 8.1 & 21.2 & 4.2 & 1.0 & 2.5 & 2.6 & \text { UL } \\ \text { NM L 26 519 } & \text { L } & 8.6 & 24.0 & 5.3 & 0.8 & 2.3 & 2.8 & \text { UL }\end{array}$

Remarks. - Ancestral Spanila gracilis differs from Spanila discipulus mainly in its generally bulkier and less dorsoventrally elongated shells, by larger umbonal angle and blunt umbos, and by more numerous radial ribs on frontal face (22-29) and posteriorly of carina (31-47).

Occurrence. - Bohemia, Prague Basin - upper Ludfordian: Praha-Velká Chuchle, Praha-Lochkov - Barrande's testpits, Praha-Slivenec, Kosoř. Uppermost Ludfordian, Cardiola conformis Community: Praha-Lochkov - Cephalopod Quarry, Praha-Pankrác - temporary outcrop for the TV Studio and Sdružení Street locality, Praha-Radotín Valley - U topolů section. Lowermost Přídolí: Praha-Radotín Valley - U topolů section.

\section{Conclusions}

1. Late Silurian Spanila Barrande, 1881 originated most probably from the Gorstian representatives of Tetinka Barrande, 1881 .

2. Spanila is represented by two species, Spanila gracilis (Münster in Goldfuss, 1837) and Spanila discipulus Barrande, 1881. Spanila gracilis appears in the middle Ludfordian, Neocucullograptus kozlowskii Biozone of Bohemia (Prague Basin), Austria (Dienten near Salzburg and the Carnic Alps), France (Montagne Noire, Mouthoumet Massif), and Germany (Frankenwald and Lindener Mark) and is most probably the direct ancestor of Spanila discipulus, which occurs together with Spanila gracilis in the late Ludfordian and earliest Přídolí of the Prague Basin.

3. Spanila is restricted to the middle and late Ludfordian and earliest Přídolí and was adapted to the specific semiinfaunal to infaunal mode of life in the cephalopod limestone biofacies of Perunica and European peri-Gondwana.
The assumption of semi-infaunal mode of life is supported by the impressions on the shells caused by cyrtiid brachiopods, attached by their triangular ventral interarea above the level of the sediment. Later infaunal mode of life is supported by the abundant occurrence of the shells with conjoined valves in the living position with the frontal face down and parallel with bedding plane.

4. The middle and late Ludfordian and early Přídolí occurrence of Spanila represents an important taxon-range-zone in the cephalopod limestone facies and may be correlated with the interval from late Neocucullograptus kozlowskii Biozone (middle Lufordian) to the early Monograptus parultimus Biozone (early Přídolí).

\section{Acknowledgments}

I am indebted to John C.W. Cope, National Museum of Wales, Cardiff, for valuable suggestions, constructive comments and linguistic improvement and to Štěpán Manda, Czech Geological Survey, Prague, for the technical help with manuscript, for the digitalization of the schematic picture and for good suggestions. Vojtěch Turek and Martin Valent, National Museum, Prague and Winfried Werner, Bayerische Staatsammlung für Paläontologie und Geologie, München kindly provided access to the collections. The research was funded by GA ČR (Czech Science Foundation) project 205/09/0703.

\section{References}

BARRANDE, J. 1881. Systême silurien du centre de la Bohême. Classe des Mollusques, ordre des Acéphalés. 6. 342 pp., 356 pls. Prague \& Paris.

BoshOFF, P.H. 1968. A preliminary study on conchological physio-pathology, with special reference to Pelecypoda. Annals of the Natal Museum 20(1), 199-216.

BOUČEK, B. 1941. O variabilitě ramenonožců Dayia navicula (Sow.) a Cyrtia exporrecta (Wahl.) a o použití metod variační statistiky v paleontologii. Rozpravy II. tř́dy České akademie věd $L(22), 1-27$.

CONRATH, P. 1887. Über einige silurische Pelecypoden. Sitzungsberichte der Kaiserlichen Akademie der Wissenschaften, Mathematisch-naturwissenschaftliche Klasse 96, 40-51.

FERretTI, A. \& KŘíž, J. 1995. Cephalopod limestone biofacies in the Silurian of the Prague Basin, Bohemia. Palaios 10, 240-253. DOI $10.2307 / 3515255$

FISCHER, P. 1880-1887. Manuel de conchyliologie et de paléontologie conchyliologique ou histoire naturelle des mollusques vivants et fossiles. 1880, pp. 1-112; 1881, pp. 113-304; 1882, pp. 305-416; 1883, pp. 417-608; 1884, pp. 609-688; 1885, pp. 689-896; 1886, pp. 897-1008; 1887, pp. 1009-1369. F. Savy, Paris.

GOLDFUSS, G.A. 1837. Petrefacta Germaniae. Abbildungen und Beschreibungen der Petrefacten Deutschlands und der angrenzenden Länder, 6. Lieferung = Teil II, 3, 141-224. 
GREILING, L. 1962. Das Silur und Devon des Schübelberges bei Elbersreuth Bayerische Fazies des Frankenwaldes. Neues Jahrbuch für Geologie und Paläontologie, Jahrgang 1969, 513-547.

HAVlíčEK, V. \& ŠTORCH, P. 1990. Silurian brachiopods and benthic communities in the Prague Basin (Czechoslovakia). Rozpravy Ústředního ústavu geologického 48, 1-275.

HEDE, J.E. 1915. Skånes Colonusskiffer. Lunds Universitets årsskrift, N.F. 2 11(6), 1-65.

HELLER, T. 1925. Die Fauna des obersilurischen Orthocerenkalks von Elbersreuth. Geognostischen Jahrensheft 1925, 38, 197-276.

HERITSCH, F. 1929. Faunen aus dem Silur der Ostalpen. Abhandlungen der Geologischen Bundesanstalt 23(2), 1-183.

IVANOVA, E.A. 1962. Ekologiya i razvitie brachiopod silura i devona kuznetskogo, minusinskogo i tuvinskogo basseynov. Trudy Geologicheskogo Instituta Akademii nauk SSSR 88, $1-152$.

KeGEL, W. 1953. Das Paläozoikum der Lindener Mark bei Giessen. Abhandlungen des Hessischen Landesamtes für Bodenforschung, Heft 7, 1-55.

KŘíž, J. 1969. Genus Butovicella Kř́iž, 1965 in the Silurian of Bohemia (Bivalvia). Sborník geologických věd, Paleontologie 10, 105-139.

Ǩ̌íž, J. 1979a. Silurian Cardiolidae (Bivalvia). Sborník geologických věd, Paleontologie 22, 5-157.

KŘíž, J. 1979b. Silurian epibyssate bivalves of Bohemian type in the Prototethys Region. XIV Pacific Science Congress, Committee B 3, 38-40. [in Russian]

KŘíž, J. 1996. Silurian Bivalvia of Bohemian type from the Montagne Noire and Mouthoumet Massif, France. Palaeontographica, Abteilung A 240, 29-63.

Kř́ǐ̌, J. 1998. Recurrent Silurian-lowest Devonian cephalopod limestones of Gondwanan Europe and Perunica, 183-198. In LANDING, E. \& JOHNSON, M.E. (eds) Silurian cycles: Linkages of dynamic stratigraphy with atmospheric, oceanic, and tectonic changes. New York State Museum Bulletin 491, 1-327.

KŘíž, J. 1999a. Bivalvia dominated communities of Bohemian type from the Silurian and Lower Devonian carbonate facies, 229-252. In Boucot, A.J. \& LAwsOn, J.D. (eds) Final report, project Ecostratigraphy. Paleocommunities: A case study from the Silurian and Lower Devonian. 895 pp. Cambridge University Press, Cambridge.

KŘíž, J. 1999b. Silurian and lowermost Devonian bivalves of Bohemian type from the Carnic Alps. Abhandlungen der Geologischen Bundesanstalt 56, 259-316.

Kříž, J. 1999c. Silurian Bivalvia - evolution, palaeontology, palaeobiograophy, importance for biostratigraphy and correlation. Abhandlungen der Geologischen Bundesanstalt 54, 377-384.

Kříž, J. 2001. Enantiomorphous dimorphism in Silurian and Devonian bivalves; Maminka Barrande, 1881 (Lunulacardiidae, Silurian) - the oldest known example. Lethaia 34, 309-322. DOI $10.1080 / 002411601753293060$

KŘíž, J. 2007. Origin, evolution and classification of the new superorder Nepiomorphia (Mollusca, Bivalvia, Lower Paleozoic). Palaeontology 50(6), 1341-1365.

DOI 10.1111/j.1475-4983.2007.00720.x

KŘíž, J. 2008. Algerina gen. nov. (Bivalvia, Nepiomorphia) from the Silurian of the North Gondwana margin (Algeria), periGondwanan Europe (France, Italy), Perunica (Prague Basin, Bohemia) and the Siberian Plate (Tajmyr Basin, Russia). Bulletin of Geosciences 83(1), 79-84.

DOI 10.3140/bull.geosci. 2008.01.079

KŘíž, J. 2010. Silurian Kenzieana Liljedahl, 1989 (Bivalvia, Spanilidae) from Bohemia, Gotland and Sardinia. Bulletin of Geosciences 85(1), 53-60. DOI 10.3140/bull.geosci.1187

LILJEDAHL, L. 1989. Two micromorphic bivalves from the Silurian of Gotland. Paläontologische Zeitschrift 63, 229-240.

LINNÉ, C. 1758. Systema naturae per regna tria naturae, secundum classes, ordines, genera, species, cum characteribus, differentiis, synonymis, locis. Edit Decima, reformata. 824 pp. Holmiae.

MÜNSTER, G.G. 1840. Die Versteinerungen des Uebergangskalkes mit Clymenien und Orthoceratiten von Oberfranken. Beiträge zur Petrefacten-Kunde 3, 33-121.

NEWELL, N.D. \& LAROCQUE, A. 1969. ?Family Lunulacardiidae Fischer, 1887, N295-N297. In MOORE, R.C. (ed.) Treatise on invertebrate paleontology, Part N, Mollusca 6, Bivalvia, Vol. 1. xxxviii +487 pp. Geological Society of America \& University of Kansas Press, Boulder \& Lawrence.

RŮŽIČKA, B. \& PRANTL, F. 1960. Genotypy některých Barrandových rodů staroprvohorních mlžů (Pelecypoda) [Types of some Barrande's Pelecypods (Barrandian)]. Časopis Národního musea, Oddíl př́rodovědný 1960(1), 48-55. [in Czech, short English summary, p. 53.]

StaRoBogatov, Y.I. 1977. Sistematicheskoje polozhenije konokardiid i sistema paleozoiskikh Septibranchia (Bivalvia). Byulleten Moskovskogo Obshchestva Ispytatelei Prirody, 125-139.

SYSTEMATICS ASSOCIATION COMMITTEE FOR DESCRIPTIVE BIOLOGICAL TERMINOLOGY 1962. Terminology of simple symmetrical plane shapes, Chart 1a. Taxon 11, 145-156, 245-247. DOI $10.2307 / 1216718$ 